\title{
An Analysis of Class-As-Race and Gender Ideology in the US Young Adult Sports Novel Racing Savannah (2013)
}

\author{
ROCÍO RIESTRA-CAMACHO* \\ University of Oviedo (Spain)
}

Received: 04/11/2019. Accepted: 15/09/2020.

\begin{abstract}
Equine fiction is an established genre in the English juvenile literary canon. Current works in the field appeal to adolescent readers thanks to their interface between classic motifs of vintage and contemporary forms of equine narratives. Performing a close reading of selected passages in Miranda Kenneally's Racing Savannah (2013), this paper acknowledges how this novel is a revitalization and a challenge to this pattern. Savannah, who is more gifted than her companions, is subordinate to the decisions of the junior of the household where she works. Jack Goodwin, the protagonist's romantic lead, educated in a neocolonialist background of male jockeying, becomes Savannah's marker of difference according to her sex and lower socioeconomic status, which lay at the root of her later racialization despite her being a white character. My analysis attempts to expose how these difficulties encountered by the protagonist to become a professional jockey articulate past and present constraints of the horse-racing ladder.
\end{abstract}

KEYWORDS: YA Equine Fiction; US Contemporary Fiction; Class-as-Race; Gender.

\section{INTRODUCTION}

Formal horse-racing in the United States dates back to the 1660s. In 1665, a racecourse was opened on the Hempstead Plains, an area currently in New York. It became truly widespread, however, two centuries later. In the nineteenth century, owing to the popularity of thoroughbreeding, or purebred horse upbringing, the United States became home to some of the best-

*Address for correspondence: Amparo Pedregal Street, no number, Department of English, French and German Philology, Faculty of Philosophy and Letters, University of Oviedo, Spain; e-mail: riestrarocio@uniovi.es 
known horse races. Contrary to popular belief, even though horse-racing was a vital source of wealth for white landowners, a great part of the training, care and racing of the horses was carried out by enslaved and free men of colour (Lambert, 2015: 622).

Given the role of the horse in the Anglo-American imaginary (Dawn, 2009), it is unsurprising that the literary market has maintained a niche for this topic to the present day. According to Kendrick, "the market seems fairly robust, as a cursory visit to the Canadian, UK, and US Amazon websites demonstrates" (2009: 183). The genre first appeared during the 1920s in Britain, a decade during which these stories were markedly popular among girls, and focused mainly on them as protagonists (Haymonds, 2004: 58). Today, equine fiction seems to be particularly connected to young adult romantic fiction (Haymonds, 2004: 58), where Racing Savannah, the novel object of study here, fits. In that sense, contemporary pieces are not very far from early pony stories (for a bibliography, see Singleton, 2013: 91), which also attracted young girls on the basis of romance featuring prominently in them. As Haymonds notes, "it was adolescent girls who were most receptive to this new obsession for horses" (2004: 484). However, vintage stories were also appreciated among boys, featuring them as protagonists, accordingly. Significantly, this is the trend mostly pursued in US equine fiction, which has historically focused on cowboy characters. As O'Malley underlines, "in sharp contrast to the British stories, in the United States boys dominate in most popular children's books about horses" (2019: 78), having mostly represented "the wild horse story" (Haymonds, 2004: 357).

In 1929 the Pony Club was established in Kenilworth, England, which can be claimed to have contributed to the success endured by pony novels by the next decade. At this point, the genre had established itself with a fairly important quantity of girl readers who craved for the formulaic conventions of the books. Following Haymond's review, the next sequence of events could be found in almost every early British pony book: "A young girl [...] longs for a pony but cannot afford one; she finds a special pony [...] learns to ride and look after it properly and, in the process, gains confidence and a skill; something threatens the status quo, often lack of money, and it seems the girl may lose the pony; however, in the end, she rides it to success in a show" (2004: 357).

A reason why the target audience of vintage juvenile equine fiction was markedly gender biased is related to how the protagonists were constructed. Particularly, the plot often presented a conflict between the femininity of the girls and the kind of risk-taking physical behaviour associated to horse-riding (Singleton, 2013: 92). As Singleton argues, vigorous physical activity was certainly present in these stories. Nonetheless, the topic often collided with motifs such as friendship, child care and, significantly, romance (2013: 94). These aspects seemed to prevent equine fiction from portraying a truly liberal type of female 
protagonists, since these rarely forgot that there was a feminine side to maintain no matter how adventurous and confident they felt about horse-riding.

Moving on to the Second World War, the popularity of equine fiction suffered a temporary decrease. After the conflict, however, pony stories "became a torrent" (Kendrick, 2009: 187). In 1941, Walter Farley's The Black novels and Mary O'Hara's My Friend Flicka were published, soon becoming two of the most appreciated wild west stories in the United States (Haymonds, 2004: 485). There were, notwithstanding, changes in character construction that paid homage to post-war society. Now heroines had to, for example, combine work and family obligations to stay afloat (Haymonds, 2009: 187). These stories marked the class of the female protagonists as low or middle more clearly than earlier books, where they were perceived as upper class (Kendrick, 2009: 187), even though, following Haymonds' argument above, this was only a perception, since "the families in these stories are [...] seldom well off [...]. Pony books are obsessed with lack of money, not wealth" (2003: 358-359). This argument is in line with Badger, who claims that money was a problem in "the vast majority of [...] pony books" (2019: 5).

Something similar happened in Britain. After the war, there was an avalanche of equine fiction books that married well with the resurgence of the popularity of horse-riding encouraged by the now booming Pony Club. The Pony Club, indeed, was in vogue along the 1940 s and as a result, during the 1950s, many "mediocre pony stories were trotted out" (Haymonds, 2004: 486). The trend continued until the 1960s, when equine fiction sales started plummeting. In the 1970s, only Patricia Leitch temporarily livened the pony story.

In the 1980s and 1990s, the equine story resurged to, nonetheless, encounter a shortage of new writers. Only names like Caroline Akrill added some novelty to the market. On the contrary, well-known writers were demanded by reading audiences again. Jean Slaughter Doty, Lynn Hall or Glen Rounds did succeed in revitalizing the genre as established novelists in the United States. In Britain, the publication of Allen Equestrian Fiction, a series trying to recuperate the old ways of equine fiction, ran unsuccessful (Haymonds, 2004: 488). At the turn of the century, the trend moved towards series books in the United States - The American Saddle Club continued to be published until recently by Bonnie Bryant. In Britain, in turn, the series from the 1990s tend to be targeted at younger readers than their American counterparts. Hollywell Stables (1995) is a representative example in the trend of children's reads.

Regarding contemporary US pony stories, Singleton claims that the literary teen market maintains "the popularity [of] these stories [...] to the present day, especially for girls" (2013: 91). In order to accommodate to present-day readers, the genre has adapted its formulaic plot. Now, the story begins with the young protagonist undergoing a turning point in her life, often in the form of loss, which leads to her feeling powerless over her life. The death of a loved one, and/or the divorce of the parents are popular topics of choice 
(Singleton, 2013: 100-101). As Singleton contends, these problems are "more likely to strike a spark of recognition from some readers than the [...] over-the-top escapades of vintage heroines" (2013: 101). On the other hand, while the wild west motif is still present, the genre has very significantly been influenced by British vintage pony fiction and so becomes "placed firmly in a rural, domestic setting and enclosed stable yard, with riding perceived as a leisure or sporting pursuit" (Haymonds 2000: 57), more relatable to today's American readers, for whom "horseback riding is an accustomed form of leisure physical activity" (Singleton, 2013: 98).

There are further links between these stories and the more classic British plots of the twentieth century, however. Of special relevance is the femininity and romantic motif, which feature prominently in equine fiction, as it was aforementioned. Young women character's femininity, particularly, is still constructed as "caring, maternal, heterosexual and dependent on masculine readership and strength" (Singleton, 2013: 92). The femininity of physically active protagonists, nonetheless, does rarely appear in stark opposition to masculinity, and character traits tend to be mixed, in opposition to earlier novels. The dependence on men, conversely, operates in the plot granting the presence of a romantic relationship great relevance. Current girl protagonists, it appears, want to feel validated in their adventurousness and in their femininity by these romantic and heterosexual attachments. There is no longer a focus on the fixation with the horse for the young protagonists.

Significantly, however, female protagonists are dependent on their own self-validation now, as well. Expressly, contemporary equine fiction places a "subtle emphasis on selfsurveillance and embodiment" (Singleton, 2013: 92). Specifically, Singleton claims that "contemporary performances of femininity appear to be self-generated and self-imposed through self-scrutiny, thoughtful reflection, and close attention to others' responses" (Singleton, 2013: 106). It is unfortunate that the author does not elaborate more on this topic, given the relevance of corporeality — especially a disordered one- among young adolescent girls, target readers of this genre, and considering the notoriety of eating disorders among horse-jockeys (von Hippel et al., 2017: 1).

The case put forward by Miranda Kenneally in Racing Savannah is, therefore, of high interest to studies of equine fiction. Savannah is the protagonist and autodiegetic narrator of this novel, a contemporary young adult equine piece published in the United States by author Miranda Kenneally in 2013. In the story, the young girl has recently moved from Kentucky, where she trained horses for the Casino, to Tennessee. The turning point takes place after her family entered a state of bankruptcy due to her mother's cancer treatment, which ran unsuccessful, and her father was offered a job at an opulent farm there. Adding to the distress of the young Savannah is the fact that her parents had divorced from each other, as her father had begun dating a woman, much younger than her mother, who is also pregnant with 
Savannah's father's child. To complicate the situation further, from the onset of the novel Savannah becomes infatuated with the youngest of the Manor's owners, Jack Goodwin, only to realize that he is the one running the farm and, therefore, her boss.

In a nutshell, Savannah embodies the intersection of past and present concerns of equine fiction's young girl readers across an ambivalent intersection between the British and US equine tradition. Not only is she, at first, a jockey discriminated on the basis of her sex and social class but altogether ostracized on the basis of her different stock or, as it will be seen, of her race. Class, and attitudes associated to it, have the opportunity to surface in the novel in subtle but interesting ways that connect it to racial ideology, which can be textually deconstructed through the close reading of a selection of passages which hint at the ambiguous characterization of Savannah, a white character, as a racialized one. Throughout the novel, these are scattered; hence, for reasons of clarity, I decided to examine them following the evolution of the relationship between the protagonist and her romantic attachment. To perform such analysis, the first part in the next section examines the interrelation between class and race through the concept of "class-as-race", and its interaction with gender. Together with the historical revision of equine fiction, these discussions constitute the theoretical framework against which the analysis of Racing Savannah is carried out in the last part of the section.

\section{CLASS-AS-RACE IDEOLOGY AND GENDER IN RACING SAVANNAH}

In this analysis, I claim that discourses of class, race and gender, in their socio-historical interrelations, can surface at once in one novel. The intersection of these categories has been discussed by a vast range of thinkers, all agreeing upon the fact that gender, race and class cannot be considered separate power structures. Gender and class are co-produced (Scott, 2018, 66) and crossed through race, and the recognition of this fact by intersectional feminism has contributed to disrupt "notions of a homogeneous category 'woman' with its attendant assumptions of universality" (Brah, 2004: 82). In Racing Savannah, class and race operate as two sides of the same coin, intertwining to form what is known as "class-as-race ideology". Geraldine Heng defines it as "the ability of racial logic to stalk and merge with other hierarchical systems — such as class, gender, or sexuality" meaning, in the case of this analysis, that class functions as race $(2018,20)$. Class-as-race ideology is certainly relevant to the thorough-breeding context depicted in the novel. As Dawn puts it, "in America, class was, in large measure, racial and ethnic" and "racism and social class find a useful metaphor in the ideological intersection of the horse and eugenics", particularly represented in the metaphor of the Thoroughbred (2009: 210). Just as it happens in real life America, in equine fiction there is a strong code of values attached to horse-riding which resonates vividly with a "traditional English code of fair play, sportsmanship and good manners" (Haymonds, 2004: 482). Paradoxically enough, however, race often stays undiscussed in novels and films 
dealing with the equus, at least explicitly. The result of this is that aristocratic whiteness (Dawn, 2009: 194-95; 235), which is also male, is assumed about those running the business.

There is, in parallel, a tendency to reject or reticence to accept women or people of colour into horse-riding. As Birke and Thompson argue, "human and horse interactions run on binaries of male/female and upper/lower which remain resilient to change, while at the same time undergoing a constant evolution" (2017: 74). The reason for this discrepancy has been noted from a socio-historical perspective. Adelman and Thompson put forward how "equestrian cultures are often cast in narratives that contrast past and present, 'tradition' and 'modernity' in complex and contradictory ways" (2018: 8). As a consequence, selective ties to the past are created in the present (2018: 8). In particular, the trend is "symptomatic of the resurgence of conservative nostalgia for idealized nineteenth-century values in American culture that seeks to stabilize ideas of race, class, and especially gender" (Dawn, 2009: 2). Despite this ambivalent rejection of women, in the US they represent the $80 \%$ of total riders (Pickel-Chevalier, 2017: 126). This reticence, exactly, is present in the novel object of study here.

The cover of Racing Savannah invites readers to identify with a young girl, dressed in contemporary clothes and a pair of strident yellow wellies, whose colour and material is a trait of low-class African American riders (Wahl, 2017: 46, 53, 56). This contrasts with the image of the boy next to her, dressed in leather boots, and the information we encounter as we first open it: "Welcome to Cedar Hill Farms of Franklin, Tennessee. Est. 1854. John C. Goodwin III, Owner" (Kenneally, 2013: 1, italics added). From the onset, there are references to the Victorian aristocratic background of the farm. The narrator herself, after spending her first couple of days there, muses "I used to exercise racehorses at the track and casino in Charles Town. But that was at a totally different level-the horses I rode there were like driving a Ford and here they are like Ferraris. Hell, the Queen of England stables her horses thirty minutes away" (2013: 2). The last observation, particularly, shows, through a hyperbole, how the narrator perceives herself to be of ignoble origins in comparison to the space she is now inhabiting. The simile established between the descent of the horses and car's luxury brands denotes a sense of alienation, which affects how she perceives herself as socially inferior in relation to the horse-riding business. In this vein, she continues drawing comparisons, which soon affect how she sees the Goodwins as superior to her and her family, given their stock differences: “I haven't met the owner's son yet, but I've seen him riding around like he's king of the place. Which is technically his title, I guess" (2013: 4). This reflection inaugurates the protagonist's self-distancing from the main male character of the novel. Significantly, prior to that appreciation, Savannah had described her first impression of him as follows: "from the fields beyond the manor house, a guy comes riding up on a horse" (2013: 4). Her description resonated with the romantic love motif of a prince 
charming, emphasized through his triumphant entrance from the grounds of the villa. This view of Jack Goodwin, in fact, already announces a romantic attachment that the protagonist will undergo and which will run into difficulties due to the war of the classes between the families.

Savannah's interest in Jack Goodwin and the fact that she cannot become a friend of his for these reasons is depicted as painful. Actually, the narrator has to provide a rationale for not approaching the boy at first, presumably to protect her self-esteem: "We were instructed to keep our distance from the Goodwins. Since I don't want Dad to get fired on day three, I haven't spoken to the boy" (2013: 4). This clearly shows how she is interested in him but their social distance obliges her to keep herself apart. After the first sight caught of Jack, later, the protagonist is able to miraculously catch Star, the newest equine acquisition of the Goodwins' farm, after it had fled and almost injured its jockey. On this first encounter, Jack addresses Savannah in a casual manner: "If I didn't love that horse so much, I'd send him to drag a tourist carriage in New York City", Jack says in a deep Tennessee drawl. [...]...So what can I do you for?" He tips his cowboy hat in an exaggerated manner and smiles again, revealing perfectly straight white teeth" $(2013,5)$. Savannah's attraction to him, significantly, is made explicit as she reflects "behind closed lips, I run my tongue over my slightly crooked front ones" (2013: 5).

The downgrading of her teeth, in contrast to his, tentatively suggests that the protagonist's inferior status affects her sense of corporeality, in a way that makes her feel physically inferior to Jack. Then, there is also the fact that she keeps her liking of him private, not even daring to mention it ("behind closed lips"), whereas Jack continues talking and, indeed, actively flirting with Savannah: "Soo...Do you want a private tour? You know, to say thanks for catching my horse?" (2013: 5). At this, Savannah reasons that "hanging around people like Jack is not my thing" (2013: 5). This reflection supports the idea that she is attempting to self-protect her ego. Jack, nonetheless, continues attempting to seduce Savannah. He notices that they "haven't met" and hence reacts by "thrust[ing] a hand out, grinning" (2013: 6). This gesture is certainly relevant to note. It not only denotes professionalism, but indexes that Jack is treating Savannah as an equal and therefore showing a friendly sense of respect towards her. In his next attempt to appeal to Savannah, he, moreover, proposes "scort[ing]" her, since Savannah is about to leave to the house. The narrator reflects on how "primitive" the proposal sounds (2013: 6). Nonetheless, the formality functions as a display of good manners on the part of Jack.

The next exchange between the young characters introduces the turning point in the story. Jack becomes curious, exactly, about Savannah's social background, asking her whether her "dad own[s] a farm" at what Savannah ponders incredulously "I laugh again. Me? Own a farm?" (2013: 7-8). Acknowledging that the social difference between them is actual, contrary to Jack's speculations about Savannah's upbringing, the protagonist develops 
an anxious attitude: "I reach into my back pocket to grab a sucker-an orange one. You know how some people take antianxiety meds? Well, I eat candy. I rip off the crinkly wrapper and stick the sucker in my mouth. Instant relief' (2013: 8). This moment anticipates Savannah's disappointment about the difficulties in having a relationship with the junior of the Goodwins. Jack continues inquiring "who are you? [...]. Did you come with Senator Ralston to meet with my father today? Are you related to him?" (2013: 8). In a replica of Savannah's last thoughts, she muses "me? Related to a senator? I look down at my holey jeans, boots, and tight black T-Shirt" (2013: 8). This instance indicates that the protagonist feels "out of place", something racialized jockeys also experience. As Wahl notes, "those bodies that [...] do not pass as inhabiting whiteness [...] experience a disruption" often being "physically blocked, noticed or questioned in public spheres ("why are you here? Where did you come from?")" (2017: 13). Her thoughts continue in this vein: "I'm about to fess up that I've just moved into the Hillcrest dungeons and therefore he and I can never speak because his family values their privacy when a man storms out of the house and up the hill to us" (2013: 9, italics in the original). It is significant that at this point Savannah attributes the impossibility for them to develop a closer relationship to privacy, rather than social difference. Nonetheless, it is relevant to note that the ultimate consequence of acknowledging this is that, to the eyes of the narrator, they cannot speak. This is a clear indication of how social difference interferes with linguistic exchanges, even preventing one of the speakers involved from producing them.

Returning to the main course of events, the man in question happens to be $\mathrm{Mr}$. Goodwin, Jack's father. Upon realizing how similar she looks to her father, he inquires "are you Danny Barrow's kid?” (2013: 9). After confirming this, Jack's evaluation of Savannah changes completely: “Jack furrows his eyebrows. You're the new groom's daughter?" (2013: 9), indexing his disappointment at Savannah's socioeconomic status. Mr. Goodwin's reaction is also worth noting, as he appears nervous "drag[ging] a hand through his hair" and prompting his son to go to his office (2013: 9). Jack's facial gesture and his father's awkwardness indicate that dialoguing with Savannah is not considered appropriate. Mindful of his father's negative impression of Savannah, "his voice chang[es] from casual to super serious. Nice to meet you, Savannah. If you'll excuse me. Then he disappears into the house with this father and the three hounds at his ankles" (2013: 9).

Keating contends that "variations in ways of talking" like these are exactly related to "local theories of power, status, identity, self, ethnicity, class, and gender" (2009: 1). Admittedly, as it has been seen in the dialogues hitherto quoted, Jack's way of addressing Savannah —including the casual Tennessean drawl and the address form "you"- suggest proximity and treatment as an equal. On the other hand, referencing her by her name after discovering her origins is a change in address which indicates a social distancing from her. 
Aware of the existing difference between them, now it becomes understandable that Savannah remained silent for the most part of the conversation. The move was not solely due to her attempt to cover for her origins; it was also a direct consequence of her being conscious of having to stay silent due to the existing social gap. Jack's hat removal - a nod to vintage US equine fiction and its motif of the cowboy - hand shaking gesture and smiles at Savannah, in turn, can also be accounted for now as signs indexing absence of social distancing. The change in voice and form of address adopted by Jack, acknowledged by the narrator, makes explicit this discourse change. The protagonist, in fact, concludes "now that Jack knows who I really am, the groom's daughter, he doesn't even give me a second glance. Figures" (2013:10).

Once Savannah has been established as an Other on the basis of her social class, and her racialized condition has been hinted at, further discrimination begins to apply. These pertain to her construction as a potential horse-rider. Particularly, sex is the new category through which "otherization" (see Holliday, Hyde \& Kullman, 2004) is strengthened and by which she will be prevented from becoming a jockey. Regarding race, it should be pointed out that Savannah is a mainstream white character, making her suffering incomparable to those of African Americans but who, nonetheless, becomes racialized as inferior to the Goodwins. Patterns reminiscent of colonial times soon establish a difference between upper and lower characters. Initially, it is worth calling attention to how during the nineteenth century in Britain, the law "permitted only gentlemen to race" and "early horse racing in America tended to replicate the British model" (Dawn, 2009: 202). Only white men of a high social class are considered worthy of racing high-quality horses, in case the lower status of a woman or of an immigrant (2009: 203-10) affected the performance of the horse. Put simply, good horses "remain forever closed to outside blood" and racing in particular "jealously guards the blood of the Thoroughbred" (2009: 194). Star is, not coincidentally, a Thoroughbred, descendant of Nasrullah and Man o' War (Kenneally, 2013: 70). Following the cultural metaphor of the Thoroughbred, Savannah's "pedigree" to be a racer is questioned on an imaginary argument of race and purity (Dawn, 2009: 195). In other words, the Goodwin's horses can only be victorious and the Goodwins successful provided that they are able to only relate themselves and their horses to the best. This downplays anecdotal references to the motif of Jack Goodwin as a cowboy, further placing the manor and its inhabitants closer to the British model of horse-riding (Wahl, 2017: 26), as well as to the British literary equine tradition.

Savannah, significantly, is a woman. From the beginning, her sex difference is equally questioned with regard to riding horses. Even her own father does when claiming "I thought you were gonna work as an exercise boy" (2013: 173, italics added). This is not the only occasion in which she is addressed as an exercise boy. Although jokingly, Jack tells her that "being an exercise boy is a man's job" (2013: 19). Furthermore, a rider from the Goodwin's 
staff takes to offend her by claiming that "women don't belong on the racetrack! Go make me breakfast" (2013: 162), trying to prevent her from even attempting so. Being a woman, however, turns to her advantage once it is discovered that Star is afraid of men and can only be ridden by women. At first, Jack becomes desperate because Star continuously kicks jockeys and, as a result, loses all its races. He laments himself several times about his - " $\mathrm{He}$ shouldn't be losing. Not with his breeding. That's all horse racing is. Breeding." (2013: 65). These complaints announce that there is room to cancel assumptions about sex biases and class-as-race attitudes because, in fact, breeding is not all that matters. In Savannah's case, sex difference is determinant for riding Star to success.

Savannah's lower social class is in her favour to drive the Goodwin's horses, on the other hand, because the higher status of the horses here, in comparison with the cheaper ones she used to ride at Kentucky, can be used as an argument to be let race. In trying to convince Gael, the manager of the Goodwins' horses, Savannah claims " "I bet riding a Goodwin horse is safer than the ones I used to ride" (2013: 15). He replies that, however, he cannot help Savannah to get the job as an exercise trainer. Confused, Savannah answers "So whose decision is it?' 'Mine' [...]. I twirl around to find Jack Goodwin [...]. Jack uses his super serious voice, like when he discovered who I really am" (2013: 16). As it can be seen, language variations feature markedly once again to acknowledge differences in power. In this case, Jack is not only superior in class to Savannah; his status is also because, as her boss, he is the one who makes the final decisions. His role as a businessman also influences his power in this sense. Notwithstanding, it also serves Jack to himself support Savannah in front of Mr. Goodwin, and give her a chance to start working as an exercise rider with Star. When Jack's father appears, he inquires his son about the reason why everyone is gathered around Savannah and not working, and the following dialogue ensues: "I might hire Savannah as an exercise rider'. Mr. Goodwin stares me down. 'What?' 'She had an excellent try out, and [...] she caught Star on foot [...]. 'Savannah might be a good hand in the barns. It's probably best to assign her there"" to what Jack responds "I'm trying to shore up my investment with Star [...]. If your exercise boys can't control him, I'll find one who will'” (2012: 22).

As aforementioned, in the past, only white wealthy men were considered deserving of riding Thoroughbred horses. In this context, old stereotypes reveal that Savannah is indeed regarded unworthy of riding Star, at least by Mr. Goodwin. The fact that he proposes to assign her to a minor job, not coincidentally the ones only slaves were assigned to perform when the Manor was built, reinforces the idea of how, even though Savannah is a white character, her lower class and sex are turned into a marker of lower race by Mr. Goodwin. In short, the male dominated traditional culture of the cowboy in the United States and its vintage equine fiction history excludes Savannah. The Anglicization of the manor, treading on the British cultural and literary model of upper class women as riders, displaces the 
protagonist because she is low class (Wahl, 2017: 50). Low class riders in the United States are in their great majority African Americans. Savannah is not racialized as one, but she shares with African American jockeys this "unfamiliarity" effect, producing "the idea that horses and riding is unobtainable for Othered racialized bodies" (Wahl, 2017: 30, emphasis in original). The novel, notwithstanding, opens the way for breaking the rituals associated to class-as-race and lower sex category ideology that are being applied on Savannah. Jack Goodwin, conscious that money comes before racial, class and sex prejudices, defends Savannah on the basis of her quality as a rider.

Even though he has been brave enough to turn the sides of the table now, Savannah is still dubious and attempts to suppress her feelings for Jack, reminding herself of "how Jack treated me when he thought I was here with a senator. He flirted, he asked questions, he smiled at me. It felt effortless... but he wouldn't have flirted if he'd known who I was" (2013: 29). Savannah is indeed very aware of how the class divide prevents them from having a relationship besides the one they maintain professionally. In turn, although Jack begins to show signs that he is respectful of Savannah, the context displays a stark reticence to accepting her. It is not only Jack's father but the space in itself that does so, by maintaining attitudes and elements that were prevalent in colonial times. For example, the Manor House withholds items from the period of slavery in the US, as the narrator notices: "on my way to Hillcrest to retrieve my riding gear, I skirt the stone wall that doubles as a fence bordering the property. Mom once told me, "They call them slave walls"' (2013: 11). Later on, readers learn that Cedar Hill, and other farms in the area, have been "around since the Civil War" (2013: 30). As such, it has preserved a distribution of the spaces in the house on the basis of role and status differences which allocates the staff to the inferior part of the house while the Goodwins live luxuriously on the first floors. On this, Savannah explains that she and her family "are sharing quarters with six other staff members and their kids" (2013: 2). Significantly, there is also a bell system inside of the house, which alerts servants of pressing needs the family may have.

This characterization of space as being related to the slavery period constitutes more than a passing nod to history. Jack's father does not only preserve colonial elements in the architecture of the house, his attitude is also reminiscent of this period. Jack comments, in fact, that he lacks a phone "because he insists on living in the prehistoric era" (2013: 61). The bell system, for instance, is not decorative, as its use is actively encouraged by Mr. and Ms. Goodwin. While describing them, Savannah acknowledges that they are useful "you know, in case there's an emergency gardening issue" (2013: 93). The irony implicit in the narrator's thoughts characterize this system as an anachronism. On one occasion, the maid's bell starts ringing. As the narrator puts it, she feels surprised because its use seems incongruous as of today. However, the chronological mismatch extends to Savannah in a crucial way. Her stepmother, who is pregnant, is indisposed to work and the young protagonist has to replace her. 
In this situation, Savannah has to serve Jack, his parents and his sister at the breakfast table. This decisive moment turns Savannah into a servant yet, it can be argued, she definitely becomes racialized as she is made bear characteristics of a slave - having been called by a bell system dating to colonial times - inappropriate due to her age and professional condition. While Ms. Goodwin assumes the situation as normal and tells her "welcome to the team" while toasting her with a teacup, Jack gets uncomfortable, as Savannah notices: "he sees me standing there and stop there and stops moving. Avoids my gaze. God. This is the most. Embarrassing. Moment. Ever" (2013: 95). In a significant move, Jack prepares coffee for Savannah afterwards. The gesture is important, for it supports the breaking of social class difference patterns, although the protagonist remains unsure of its appropriateness.

This situation, nonetheless, allows Savannah to eavesdrop a conversation between Jack Goodwin and his father which is significant to the purposes of the analysis. His father, realizing his son's awkwardness at the sight of Savannah serving them, advises him not to become too attached to Savannah because "“it doesn't look good when a businessman dates his staff" (2013: 99). The key to understand the father's rejection of Savannah, however, is provided later, when he adds "I haven't decided if she's talented" (2013: 99). It seems preposterous that Mr. Goodwin justifies his disapproval of Savannah to be dated by his son on the basis of her professional qualities at horse-racing. Nonetheless, the history of class-asrace ideology in relation to thorough-breeding sheds light on this incongruity. There is, in fact, a parallelism established between who is considered worthy of racing the horse and who is considered worthy of the company of its white businessmen owners. If Savannah cannot ride Star, because of being a lower-class young woman, she obviously cannot date Jack, either. She is, definitely, taken to be of an inferior stock or race than the Goodwins. Uncoincidentally, she has moved from Kentucky to Tennessee, and this turns her into an immigrant.

To make her racialized condition even more explicit, Savannah actually has to cover for her step-mother a second time, later that day, now at the dinner between the Goodwins and the Winchesters, another wealthy family that is into the business of horse-riding. In another historical parallelism, as Dawn notes, "some of the new-money elite who would join the Jockey Club improved their own social standing and presumably the 'blood' of their descendants when their daughters married members of the European gentry" (2009: 205). This is exactly why Mr. Goodwin encourages his son to date Abby Winchester, the daughter of this rich family from Tennessee. The clothes Savannah is made wear on this occasion are, on the other hand, downgrading. It is a maid's uniform which "if [she] looks straight down, [she] can see [her] bra" (2013: 114). In contrast, the Goodwins are wearing "chic suits" while Abby Winchester and Shelby, Jack's sister, "look straight out of a movie with their sparky 
cocktail dresses" (2013: 120). Savannah's almost nudity is noticed by Marcus, the junior of the Winchesters. This positions her in a truly disturbing situation where he attempts to sexually assault her, considering himself entitled to do so - "“servants want to sleep with me"” (2013: 267; italics in the original).

Meanwhile, Mr. Goodwin, Jack and Mr. Winchester discuss the selling of Churchill Downs, the farm they own. Savannah overhears them talking about how an honourable business would it be to sell it to the Goodwins, given their aristocratic upbringing. Savannah then understands that this is "why Jack has to suck up to Abby Winchester all the time" (2013: 123). This relationship, notably, would be economically beneficial for the two families, since it would allow them to join their businesses. In the past, "the Americans who saw themselves as needing greater respectability and bluer blood often hobnobbed with European aristocrats who found their fortunes declining" (Dawn, 2009: 205), tellingly. As it will be seen, once she proves her talents as a rider, she will stop being considered an inferior choice as a partner for Jack and as a jockey for the Goodwins' horses.

While his father is around, Jack, conclusively, behaves to satisfy him. It is not surprising, hence, that alterations in Jack's behaviour and discourse, namely to please Savannah, are more evident at school, when they are alone. In a friendly move, Jack sits with her to share lunch and they start playfully arguing over food. This playfulness between them, where they were even considering to share lunch as equals, contrary to when Savannah serves the Goodwins, shows that the context is what is keeping them apart. At the Manor House, Savannah is an employee and, given the colonial background of the family, this stands as a racialized status. Savannah realizes, indeed, how "at school he's so different from how he is on the farm where he's the boss" (2013: 82). Savannah's father, aware of the social divide between both families, also tries to convince her daughter to forget him because "“Mr. Goodwin would never allow his son to date you" (2013: 171). This comment makes clearer that it is a contextual difference that makes Savannah an Other. The farm is not fully run by Jack, but by his father's neocolonial mentality.

Jack finds himself at a crossroads, then. Because he likes Savannah, and the attraction is mutual, they eventually have some romantic intercourse that the protagonist mistakenly understands as a more formal event than Jack himself does. In fact, fearing of his father's opinion and the financial risk involved in dating Savannah instead of Abby, he proposes to Savannah to keep their relationship secret. This gets them in a difficult situation: when this happens, Savannah has just begun riding Star and her role as a horse-jockey is therefore unstable. Mr. Goodwin, profiting from Savannah's clumsiness during a training, convinces his son to send a male jockey to race Star in the next contest, as usual. Pissed, Savannah reflects to herself that "Jack already told me he can't date me because of who I am. And now he's taking this away from me? Asshole..." (2013: 239). Added to her lower class and her racialized status, to the eyes of Mr. Goodwin Savannah does not deserve to wear the 
Goodwins' silks. In a plot twist, Savannah's sex and class status eventually helps her to reverse the situation to her favour once more and recover her role as a rider.

Jockeys must be short and skinny to have an advantage to ride horses. Savannah, a naturally short young woman, is, moreover, rather skinny. She has, in fact, suffered from hunger as a result of her family's difficult economic situation. Two times, she compares the childhood she endured, "growing up eating the free lunch, not having much for dinner" (2013: 88), with that she desires for her sister-to-be (2013: 25). As a result, she is slim, and the main maid acknowledges this to his father: "see the bones on your girl"" (2013:26). One of the issues that Jack cares about when thinking it might be appropriate to have Savannah riding Star is precisely her weight. Nonetheless, Savannah does not show signs of ever wanting to prevent herself from eating, fearing weight gain. This is important given how relevant eating disorders are among jockeys in the United States (von Hippel et al., 2017: 1).

With the help of her low weight resulting from a difficult socioeconomic situation, Savannah, naturally liked by Star because of being a woman, starts improving at trainings once she is given a second chance by Jack. This happens after the young man realizes that Savannah's physical condition is a final argument to have Savannah riding. Her racialized status, significantly, surfaces here only to be cancelled. Specifically, Savannah does not have a jockey licence but, due to the Goodwin's influence, her "paperwork" can be achieved "in a hurry" (2013: 133). An immigrant at Tennessee, it is curious that Savannah has her jockey status fixed exactly as one would have the immigrant status resolved by the influence of a wealthy family. Now that her sex, class and race are not a problem to compete for the Goodwins' horses, she still is undeserving in Mr. Goodwin's eyes as a potential romantic partner of his son. It is only after Savannah proves that she is not only legitimately accepted by Star, but that she is also capable of riding it to success in races, that Mr. Goodwin starts accepting that his son is attracted to her.

Nonetheless, Savannah still needs to demonstrate to Jack that she is a person worthy in her own right, not a rider who is simply lucky to be accepted by Star as a woman or whose advantage depends on her lower weight as a girl from a struggling background. The novel adds a final contemporary note in its breaking of the ceilings of class-as-race ideology and sex difference bias in the world of horse-racing. Racing Savannah operates in its last chapters as a coming-of-age piece where the young protagonist decides to embody the American ideal of surmounting her upbringing. Savannah, exactly, decides to attend college: she is no longer planning to define herself as only a jockey anymore or "putt[ing] all [her] chips in horseracing" (2013: 249). Her thoughts about obtaining validation from a romantic relationship also support this maturing, since she reflects that, eventually, she does not "need a guy to feel happy" (2013: 222). This is an example of how Racing Savannah distances itself from vintage pony fiction, insisting upon the possibility that self-validation is not 
necessarily accomplished through romance. Going to college would allow Savannah "to have lots of paths to choose from" (2013: 251).

Savannah's resolution is paralleled by Jack's own to dismiss the neocolonial background and family values he has been raised in. First, the next time his father proposes to send a male racer to ride Star, Jack refuses and claims to himself the ownership of Cedar Hill. This is accompanied by his reclaiming his right to choose his jockeys and, crucially, his romantic partner. By the same token, Jack eventually decides to break with his family's past history giving Savannah an antique family heirloom to match a trinket from Claire's that her mother had given her before passing away. In this way, in a gesture that feels both symbolic and idealistic, Jack breaks the selective ties with the past of thorough-breeding class-as race and sex bias ideology. Savannah, in line with vintage equine fiction female heroines, may be of a struggling background, yet in a representation closer to the reality of today's feminized upper class horse-riding, she herself eventually accesses a well-off context. Her dexterity in horse-riding has functioned "as a "ticket in" for the young protagonist, "enabling the sensation of belonging to, or be extended in white rooms" (Wahl, 2017: 64).

\section{CONCLUSIONS}

In this paper, I have briefly traced the history of equine fiction in the United States and Britain. This background has contributed to enrich the conduction of the literary analysis of Racing Savannah later. The perspective followed in so conducting it has been that of a critical reading, which has revealed the relevance of the imaginary of thorough-breeding in the novel object of study. Thorough-breeding, as it has been seen, operates as a metaphor of class-as-race ideology that applies not only to horses in this fancy farm setting at Tennessee, but also to its young protagonist and romantic lead, who find themselves struggling to navigate their boss-employee relationship throughout the novel. The metaphor accounts for the fact that theirs is, at least temporarily, the kind of relationship between master and slave that one could find in colonial literature. This, it has been argued, affects the way both characters address each other in different situations.

The inclusion of sex bias and class-as-race ideology in this analysis has evidenced the intersection of different processes of otherizing the protagonist of Racing Savannah in a way that made neocolonial stereotypes of American thorough-breeding culture surface. Particularly, preoccupations of her lower status to function as a (girl) jockey have been linked to those pertaining to her rejection as a (girl)friend of the junior of the Goodwins. The analysis has worked throughout the ambivalence of an English classed tradition of feminine riders against its literary history of struggling heroines and the masculinized western context of US or African American female jockeys, contexts from which Savannah was out as an underprivileged white woman. This analysis, however, has also shown how this 
contemporary piece of equine fiction eventually subverts such schema, turning sex and class differences into advantages for the young protagonist, rather than markers of her difference, and horse-riding into a whitewashed practice to climb the social ladder.

\section{REFERENCES}

Alexander, S. (1995). Hollywell Stables. London: Macmillan Children's Books.

Badger, J. (2019). Heroines on Horseback: The Pony Book in Children's Fiction. Bath: Jane Badger Books.

Birke, L. \& Kirrilly T. (2017). (Un)Stable Relations: Horses, Humans and Social Agency. New York: Routledge.

Brah, A. (2004). Ain't I A Woman? Revisiting Intersectionality. Journal of International Women's Studies, 5(3), 75-86.

Dawn, A. (2009). Lyrical Beasts: Equine Metaphors of Race, Class and Gender in Contemporary Hollywood Cinema. Unpublished Doctoral Dissertation, Indiana University, United States.

Farley, W. (1941). The Black Stallion. New York: Random House.

Haymonds, A. (2004). "Pony Books". In P. Hunt \& S.G. Bannister Ray (Eds.), International Companion Encyclopaedia of Children's Literature (pp. 481-90). London: Routledge.

Heng, G. (2018). The Invention of Race in the European Middle Ages. Cambridge: Cambridge UP.

Holliday, A., Hyde, M. \& J. Kullman. (2004). Intercultural Communication: An Advanced Resource Book for Students. London: Routledge.

Keating, E. (2009). Power and Pragmatics. Language and Linguistics Compass, 3(4), 996-1009.

Kendrick, J. (2009). Riders, Readers, Romance: A Short History of the Pony Story. Jeunesse: Young People, Texts, Cultures, 1(2), 183-202.

Kenneally, M. (2013). Racing Savannah. Naperville, IL: Sourcebooks Fire.

Lambert, D. (2015). Master-Horse-Slave: Mobility, Race and Power in the British West Indies c. 1780-1838. Slavery \& Abolition. A Journal of Slave and Post-Slave Studies, 36(4), 618-641.

O’Hara, M. (1941). My Friend Flicka. Philadelphia: J. B. Lippincott.

O’Malley Halley, J. (2019). Horse Crazy: Girls and the Lives of Horses. Georgia: University of Georgia Press.

Pickel-Chevalier, S. (2017). Popular Horse Stories and the Invention of the Contemporary HumanHorse Relationship through an 'Alter Ego' Paradigm. Journal of Sports Science, 119-137.

Scott, J. (2018). Gender and the Politics of History. New York: Columbia University Press.

Singleton, E. (2013). Romancing the Horse: Adventure and Femininity in Juvenile Equine Fiction for Girls. In M. Adelman and J. Knijnik (Eds.), Gender and Equestrian Sport: Riding Around the World. (pp. 91-111). Dordrecht: Springer.

von Hippel, P., Rutherford C.G. \& Keyes, K. (2017). Gender and Weight among Thoroughbred Jockeys: Underrepresented Women and Underweight Men. Socius, 3, 1-7.

Wahl, A. (2017). Clear Round. Equestrian Embodiments-Race and Gender Matters. Unpublished Doctoral Dissertation, Södertörn University, Sweden. 